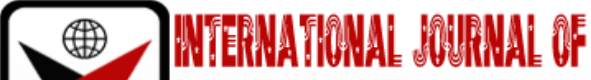

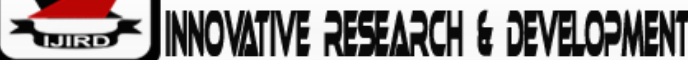

ISSN 2278-0211 (Online)

\section{Assessing Motivational and Retention Strategies Employed to Retain Academic Staff: Evidence from Selected Universities}

\author{
Violet Kimbavala \\ Assistant Lecturer, Department of Business Administration, \\ University of Iringa, Tanzania
}

\begin{abstract}
:
Academic staff is a key resource in higher education institutions (HEIs) and therefore has a major role in the achievement of the objectives of these institutions. Satisfied and well-motivated academic staff can build a national and international reputation for themselves and their institutions. Retention strategies strengthen the capacities of organizations to attract and retain their workforce. Three universities were purposely selected, namely University of Iringa (UoI), Ruaha Catholic University (RUCU) and Mkwawa University College of Education (MUCE), within Iringa municipality. Primary and secondary data were used for the study. The study findings revealed that there are strategies employed by all three universities such as provision of competitive remuneration, scholarship provision, research and consultancy opportunity, workload allowances, recruitment of retainable academic staff, scholarship provision, bounding of five years after training, gratuity payment, scholarship, extra duty/ overtime allowances, quarterly meeting with academic staff, bank loan guarantee, marking and invigilation allowances and soft loans (land). MUCE had additional strategies like land loan and quarterly meeting as feedback mechanism, while RUCU provided gratuity, UoI provided competitive remuneration and seminars/trainings. However, there are no clear and defined academic staff motivation and retention strategies in the universities under the study.
\end{abstract}

Keywords: Motivational strategies, retention strategies, academic staff, motivation, retention, universities, UoI, MUCE, RUCU

\section{Introduction}

Since the turn of the new millennium, higher and tertiary education institutions have been grappling with varied means to retain staff. They have been digging deep into their reserves in an attempt to offer staff retention strategies they perceived to be effective (Mapolisa, 2014).Where there are no clear retention strategies to retain them the ultimate goals of the institution might not be achieved (Naris \& Ukpere, 2010). Retention strategies strengthen the capacities of organizations to attract and retain their workforce. A strategic approach to employee retention may include adopting effective methods of engagements, safe and healthy workplaces and creating flexible work arrangements. Retention practices help create an inclusive and diverse workforce where barriers are reduced and individuals can carry out their duties in an acceptable manner (Kwegyir-aggrey, 2016).

The study by (Matimbwa \& Ochumbo, 2019) highlights in Tanzania just like in many African and East African countries, retention of academic staff in HLIs is low. Sokoine University of Agriculture, had over the past 20 years lost over 90 senior academic staff. University of Dar es Salaam (UDSM), over 50 senior academic staff are on leave without pay.

This study involved three universities namely, University of Iringa (UoI), Ruaha Catholic University (RUCU), and Mkwawa University College (MUCE). The study addressed the following key questions: 1 . What are the motivation and retention strategies employed to retain academic staff among the selected universities? 2. How those motivation and retention strategies are address academic staff turnover problem? The remainder of the paper is organized as follows; Section 2 identifies related works. Section 3 presents methodology. Next, Section 4 offers results and discussion, finally section 5 gives conclusion and recommendations.

As suggested by Gberevbie, (2008), motivational and retention strategies include: provision of medical care for staff and family members; maternity leave with full pay for female staff; job security; proper working environment; confirmation of staff appointment within six (6) months and two (2) years after successful confirmation interview; regular payment of monthly salaries; monetization of employee benefits; regular staff training; and regular promotion; provision of free transport (buses) to staff; loan facilities to staff; clothing allowance; observance of public holidays; end of year bonuses and awards; contribution of staff basic salary to the contributory pension fund and prompt payment gratuity to staff at disengagement from the service; provision of car and housing loans to staff; staff recognition in decision-making; prompt fulfillment of promises made by management; provision of training opportunities for staff in both local and international institutions for career progression; proper working environment; provision of incentives in form of awards to individual staff for hard work; and payment of outstation allowance. 
Author Chew, (2005) identified the following strategies; recruitment and selection, salary and compensation, fringe benefits, training and development, and performance appraisal (PA) systems, as well as promotion and career advancement.Kwegyir-aggrey, (2016) asserted that the absence of effective retention strategies such as education and training opportunities, retirement plans/ packages, and health and related benefits induce staff to leave an organization.

In their work on retention strategies and recruitment, Oginni et al., (2013) provided what should be the focus of any retention strategy in this part of the world - Africa which are job security, competitive pay, education and training or going education, recognition and reward, placement, job involvement and adequate facilitation work environment and leadership style.

(Onah and Anikwe, (2016) suggest that retention strategies, which effectively satisfy the needs of all employees consequently enhances the ability for organizations to adapt more effectively to ongoing organizational change. Research shows that trends redefining modern retention strategies go beyond the traditional salary and benefits package and compensation, embracing employee motivation, as one of the key factors to cater to the diversity and long stay of the workforce in the organization. These attraction and retention strategies include; Provision of Good Learning \& Working Climate, Job Flexibility, Recognition, Rewards and Compensation, Cost Effectiveness, and Training and Development.

A study conducted by Matimbwa and Ochumbo, (2019) on assessing motivation and retention strategies employed by these universities several issues were considered, these include raise of payment, improvement of the job security, timely induction process, offer appropriate training, training and development opportunities and effective management of expectation. Regression analysis was used to assess these factors. Upon measuring the strategies regression analysis was employed, findings depict that clear career path, job security, promotion opportunities were found to have a strong effect on academic staff retention with coefficient value of $0.5482,0.4820$ and 0.4263 respectively. These findings imply that majority of the respondents consider these three strategies as important compared to others.

\section{Study Location and Methodology}

The study was conducted in Iringa Municipality whereby three universities namely University of Iringa (UoI), Ruaha Catholic University (RUCU) and Mkwawa University College of Education (MUCE) were selected. Primary and secondary data were used for the study. Primary data were obtained through the administration of structured questionnaires and interviews to elicit relevant information on assessing motivational and retention strategies employed among those selected universities. The study employed a cross-sectional research design. It used both quantitative and qualitative tools.

The target population under this study was the academic staff in the selected universities including professors, associate professors, lecturers, senior lecturers, assistant lecturers, and tutorial assistants, with a total number of 456 academic staff. This study had a sample size of 217 respondents who represented the whole population in the area of study. A researcher employed stratified random sampling and simple random sampling so as to eliminate biasness since equal chance of inclusion in the sample was provided to the population. Purposive sampling was employed as well since a researcher aimed at obtaining information from respondents who were considered as key informants.Data were collected, cleaned, coded and analyzed using Statistical Package for Social Sciences (SPSS) and Spread Sheets. Frequencies and factor analysis were run. In order to measure nominal and ordinal data, frequencies were preferred especially for data like gender and age groups. For factor analysis, tool was used to accommodate attitudinal questions as employed in the study.

\section{Results and Discussion}

A total of 217 questionnaires were administered to the academic staff among the three universities. 200 participants completed and returned the questionnaires that are $92.2 \%$ of response.

\subsection{Respondents' Demographic Characteristic}

In the first part of the questionnaires, the informants were asked to provide personal information. The participants responded to many items appropriately, though they provided different opinions.

\begin{tabular}{|c|c|}
\hline Gender & Percent \\
\hline Male & 72.5 \\
\hline Female & 27.5 \\
\hline Total & 100 \\
\hline Age (years) & 0.5 \\
\hline Below 25 & 47 \\
\hline $25-34$ & 32 \\
\hline $35-44$ & 8.5 \\
\hline $45-55$ & 12 \\
\hline 56 and above & 100 \\
\hline Total & 28.5 \\
\hline Marital status & 67 \\
\hline Single & 2.5 \\
\hline Married & 2 \\
\hline Divorced & 100 \\
\hline Widow/er & \\
\hline Total & \\
\hline
\end{tabular}

Table 1: Demographic Characteristic of the Respondents $(n=200)$ 
The findings indicate that there were many male academic staff than female, which is $72.5 \%$ and $27.5 \%$ respectively. This may imply that males are more interested teaching in High Learning Institutions than females. Many academic staff were between 25-34 years of age which is $47 \%$ followed by $35-44$ year of age with $32 \%$. This implies that many academic staff were still young and therefore they were mobile (it is easy for them to move from one employer to another). Motivational and retention strategies are more important in this situation. In regard to respondents' marital status, many respondents were married $67 \%$, followed by single $28.5 \%$, divorced $2.5 \%$ and window/er $2 \%$. This tells that the mobile category (single) was smaller than the anticipated retained (married).

\subsubsection{Academic Rank of Staff and Duration of Working with the Current Employer}

Results show that $60 \%$ were assistant lecturers, $22 \%$ tutorial assistant, $14.5 \%$ lecturers, 3\% Senior lecturers and $5 \%$ professors. This information may as well imply that having bigger percent of assistant lectures followed by tutorial assistants, the training development is inevitable to retain them bearing in mind that this group falls between the ages of 25 to 44 years of age.

Findings show that, duration of academic staff with the current employer, 49\% were between 5-9 years of work, $37.5 \%$ below 5 years, $9.5 \%$ between $10-14$ years, and $4 \%$ have worked for 15 years and above. The findings tell that about half of the respondents were with their current university, between 5-9 years which is enough to have institutional memory.

\begin{tabular}{|c|c|}
\hline Academic Rank & Percent \\
\hline Tutorial Assistant & 22 \\
\hline Assistant Lecturer & 60 \\
\hline Lecturer & 14.5 \\
\hline Senior Lecturers & 3 \\
\hline Professor & 0.5 \\
\hline Total & 100 \\
\hline Duration with the current employer & 37.5 \\
\hline Below 5 years & 49 \\
\hline 5-9 years & 9.5 \\
\hline 10-14 years & 4 \\
\hline 15 years and above & 100 \\
\hline Total & \\
\hline
\end{tabular}

Table 2: Academic Rank of Staff and Working Duration with the Current Employer $(N=200)$

\subsection{Motivation and Retention Strategies}

A researcher aimed at assessing motivation and retention strategies employed by universities to retain academic staffs in Tanzania. The question to respondents on the awareness of the availability of those strategies was asked to the respondents while administrative members were asked to mention the strategies employed by their universities through interviews. The effectiveness or usefulness of the strategy also was another question to administrative members and other respondents.

\subsubsection{Am Aware of the Academic Staff Motivation and Retention Strategies}

The findings in Table 3 show that $75 \%$ of the respondents were not aware of the academic staff motivation and retention strategies employed by the universities and $25 \%$ agreed. This means many academic staffs were not aware of the motivation and retention strategies employed by their universities. This response implies that there is no formal or deliberate academic staff retention strategies employed, and if any they are not communicated or are not clearly defined to academic staff.

\begin{tabular}{|c|c|c|c|c|c|c|c|c|}
\hline $\begin{array}{c}\text { Motivation and Retention } \\
\text { Strategies }\end{array}$ & University & \multicolumn{9}{|c|}{ SD } & Percent \\
\cline { 2 - 9 } & & SA & A & BA & BD & DA & SD & 100 \\
\hline I am aware of the academic & UoI & 1.7 & 18.6 & 1.5 & 18.8 & 50.9 & 8.5 & 100 \\
\hline staff motivation and & RUCU & 1.5 & 13 & 3.7 & 36.9 & 31.9 & 13 & 100 \\
\hline retention strategies of this & MUCE & 5.6 & 23.6 & 5.1 & 10.1 & 54.2 & 1.4 & 100 \\
\hline University & Total & 3 & 18.5 & 3.5 & 22 & 45.5 & 7.5 & 100 \\
\hline Academic staff motivation & UoI & 3.4 & 10.2 & 4.3 & 21.1 & 50.8 & 10.2 & 100 \\
\hline and retention strategies & RUCU & 2.8 & 13 & 8.6 & 32 & 33.3 & 10.3 & 100 \\
\hline employed by this & MUCE & 0 & 16.6 & 10.1 & 1 & 68.1 & 4.2 & 100 \\
\hline university are useful & Total & 2 & 13.5 & 7.6 & 17.9 & 51 & 8 & \\
\hline
\end{tabular}

Table 3: Motivation and Retention Strategies $(N=200)$

Key: SA-Strongly Agree,A-Agree,BA-Barely Agree,BD-Barely Disagree: DA-Disagree, SD-Strongly Disagree 


\subsubsection{Academic Staff Motivation and Retention Strategies Employed Are Useful}

Since many respondents seemed to have no idea of the academic staff motivation and retention strategies, the findings show that $76.9 \%$ disagreed that the motivation and retention employed are useful. This means that there is ineffective plan and implementation of strategies if any.

The interview conducted revealed that strategies are not explicit, since when they were asked whether there are any strategies employed to motivate and retain academic staff, their responses were as presented below;

- RUCU: They claimed to have an effective recruitment process whereby retainable academic staffs are recruited and selected. The employee CVs assists them to determine whether the applicant is retainable or not. They also contact their previous employers before selecting them for placement. Provision of scholarship to academic staff was mentioned as the retention strategy, where after completing their study, they bond them to work with the university for not less than five years before they are eligible to leave for another employer if they wish to.

- Provision of 'Gratuity' was another strategy they employ as well for maintaining the social welfare of the academic staff by facilitating them whenever they are in need of (they have funeral funds), health insurance membership and housing to some of the academic staff who are eligible. All these strategies were not explicitly documented as they were verbally mentioned. They claimed that documents were in progress of being documented.

- UoI: Provision of competitive remuneration, bank loan guarantee, teaching facilities like projectors, laptops, in comparison to other higher learning institutions were mentioned as their motivation and retention strategy. Scholarships, research and consultancy opportunities, and workload allowance are also provided though due to financial constrains it is not well implemented. Unfortunately, all these strategies are not documented and therefore the sustainability is uncertain.

- MUCE: Like other universities they try their level best to provide statutory obligations to its staff timely. They provide; tuition fees for upgrading courses, extra duty/ overtime, airtime allowances, and university soft loan (land).

High percentage of the respondents proved to be unaware of the strategies employed by the university management. The findings of strategies in common to all the three universities were scholarship provision, bounding after school, workload or extra duty allowances.

The findings revealed that the strategies are not documented and therefore their sustainability is questionable. However, a number of good strategies were mentioned such as provision of competitive remuneration, scholarship provision, research and consultancy opportunity, bounding after school, workload allowances, recruitment of retainable academic staff, scholarship provision, bounding of five years after training, gratuity payment, scholarship, extra duty/overtime allowances, quarterly meeting with academic staff, bank loan guarantee, marking and invigilation allowances and soft loans (land).

Despite of a good number of strategies mentioned, no any university was able to provide any document describing the list instead they claimed to be in preparation process and others in different levels waiting for authority to approve. The study therefore concludes that there are no sound and practicable strategies for academic staff motivation and retention.

The findings also found that government support through grants could be the facilitating agent to effectiveness of the strategies at public institutions rather than at private universities where they do not get government grants, they depend on school fee as a source of income which is not sustainable. More effort is required for raising reputation as well as seeking for alternative sources of income to support the implementation of their strategies.

\section{Conclusion and Recommendations}

\subsection{Conclusions}

There is no doubt that staff motivation and retention strategies create positive impact on academic staff. However, high percentage of the respondents proved to be unaware of the strategies employed by the university management. The study findings revealed that there are strategies employed by all three universities such as provision of competitive remuneration, scholarship provision, research and consultancy opportunity, bounding after school, workload allowances, recruitment of retainable academic staff, extra duty/ overtime allowances, and invigilation allowances. MUCE had additional strategies like; soft loan (land) and quarterly meeting as feedback mechanism, while RUCU provided gratuity, UoI provided bank loan guarantee. However, all these strategies are not documented, which raise a question of sustainability. Therefore, it might be concluded that there are no clear and defined academic staff motivation and retention strategies in the universities under the study.

\subsection{Recommendations}

Based on the above findings the following recommendations are made; There should be motivation and retention strategies in the universities that support staff retention. These strategies need to be aligned to organization's vision and missions for existence, growth, and expansion purposes. Universities should raise awareness of the strategies employed by the university management to academic staff. Motivation and retention strategies should be well documented. It is imperative for universities and any other related organizations to keep an eye on issues that may bring about staff turnover and be vigilant as the case may be. Universities should think of alternative funding apart from student fees only. This way will strengthen financial capability to meet staff demands such as promotion, career development, improved work environment, and other motivational aspects. Government should support through grants both public and private 
universities. Private universities depend on school fees mainly as a source of income which is not sustainable in many cases.

\section{References}

i. Chew, Y. T. (2005). Achieving Organisational Prosperity through Employee Motivation and Retention: A Comparative Study of Strategic HRM Practices in Malaysian Institutions. Research and Practice in Human Resource Management, 13(2), 87-104.

ii. Gberevbie, D. E. (2008). Staff Recruitment, Retention Strategies and Performance of Selected Public and Private Organizations in Nigeria. Covenant University.

iii. Kwegyir-aggrey, P. (2016). Assessment of Staff Retention in Private Universities in Ghana : A Study of the Perez University College , Winneba. Journal of Education and E-Learning Research, 3(4), $130-137$. https://doi.org/10.20448/journal.509/2016.3.4/509.4.130.137

iv. Machado-taylor, M. D. L., Soares, V. M., Brites, R., Ferreira, B., Farhangmehr, M., Maria, O., \& Gouveia, R. (2016). Academic job satisfaction and motivation: findings from a nationwide study in Portuguese higher education. Studies in Higher Education, 5079(January), 541-559. https://doi.org/10.1080/03075079.2014.942265

v. Mapolisa, T. (2014). Effectiveness of staff retention strategies in Zimbabwe 's public and private Universities : Returnee lecturers ' perspective. International Journal of Public Administration and Policy Research, 1(1), 820.

vi. Matimbwa, H., \& Ochumbo, A. (2019). Academic Staff Motivation and Retention in Higher Learning Institutions in Tanzania: Evidence from Selected Universities in Iringa Region. Journal of Business Management and Economic Research, 3(6), 1-14. https://doi.org/10.29226/TR1001.2019.12

vii. Naris, N. S., \& Ukpere, I. W. (2010). Developing a retention strategy for qualified staff at the Polytechnic of Namibia. African Journal of Business Management, 4(June), 1078-1084.

viii. Oginni, B. O., Ogunilust, C. ., \& Faseyiku, I. O. (2013). A Study of Employee Retention Strategies and Organizational Survival in Private Universities in South West, Nigeria. The International Journal of Management, 2(1), 1-17.

ix. Onah, F. O., \& Anikwe, O. S. (2016). The Task of Attraction and Retention of Academic Staff in Nigeria Universities. Journal of Management and Strategy, 7(2), 9-20. https://doi.org/10.5430/jms.v7n2p9

x. Osibanjo, O. A., Adenui, A. A., Olubusayo, H., Alola, F., \& MAC, P. T. H. (2014). Leonardo Journal of Sciences, 13(25), 111-116. 